\title{
Widespread occurrence of the anammox reaction in estuarine sediments
}

\author{
Joanna C. Nicholls, Mark Trimmer* \\ School of Biological and Chemical Sciences, Queen Mary, University of London, Mile End Road, London E1 4NS, UK
}

ABSTRACT: We assayed sediment for the anammox reaction at 40 sites from 9 estuaries during the summer of 2004. The anammox reaction was detected at all sites with its potential contribution to the production of $\mathrm{N}_{2}$ $(\mathrm{ra}, \%)$ ranging from $<1$ to $11 \%$. Overall, a higher contribution from anammox was positively correlated with both the concentration of $\mathrm{NO}_{3}{ }^{-}$in the overlying water and the organic carbon content of the sediment. Whilst the organic carbon content of the sediment decreased towards the coast, its reactivity remained essentially constant $\left(k=0.6 \mathrm{y}^{-1}\right)$, which suggested that the amount of organic carbon rather than its reactivity or quality was more important. In addition, our large dataset enabled us to critically assess the 2 assays for measuring anammox $\left({ }^{15} \mathrm{NH}_{4}{ }^{+}\right.$or $\left.{ }^{15} \mathrm{NO}_{3}{ }^{-}\right)$. While the 2 assays gave good agreement at $r a>3 \%\left(>2 \mathrm{nmol} \mathrm{N}_{2} \mathrm{ml}^{-1}\right.$ wet sediment for anammox after $24 \mathrm{~h}$ ), below this, though still detectable, anammox was underestimated with ${ }^{15} \mathrm{NH}_{4}{ }^{+}$. The decrease in the estimate for anammox with ${ }^{15} \mathrm{NH}_{4}{ }^{+}$relative to ${ }^{15} \mathrm{NO}_{3}{ }^{-}$was partly explained by a decrease in the recovery of $\mathrm{N}_{2}$ gas, probably as a result of significant dissimilatory nitrate reduction to ammonium (DNRA) in some of the slurries. The potential interference from DNRA in the anammox assay, however, would be low, with the probability of anamox making ${ }^{30} \mathrm{~N}_{2}\left(\mathrm{~A}^{30} \mathrm{~N}_{2}\right)$ being about $1.4 \%$. Our findings provide firm evidence that the anammox reaction is widespread in estuarine sediments.

KEY WORDS: Anammox · Estuary - Sediment . Organic carbon $\cdot$ Nitrate

Resale or republication not permitted without written consent of the publisher

\section{INTRODUCTION}

The discovery of anaerobic ammonium oxidation (anammox) in the laboratory and the environment has lead to a redefining of the classic nitrogen cycle (Mulder et al. 1995, Thamdrup \& Dalsgaard 2002). Anammox has been shown to be widespread in coastal

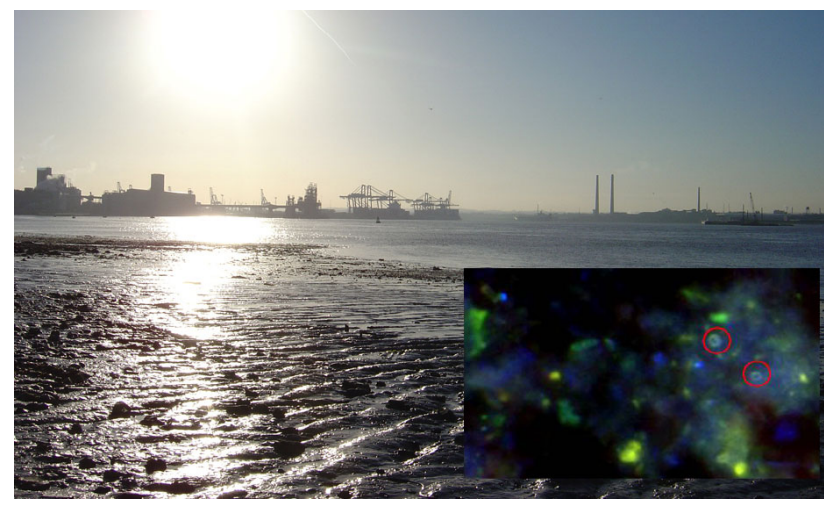

An organically enriched estuarine mudflat, combined with plentiful nitrate, provides an ideal environment for anammox bacteria.

Photos: JC Nicholls, W Mehsana

marine sediments (Rysgaard et al. 2004, Dalsgaard et al. 2005, Engström et al. 2005, Schmid et al. 2007), yet knowledge of its distribution and regulation in estuarine systems is comparatively scarce, with data reported from just 4 estuaries around the world so far (Trimmer et al. 2003, Risgaard-Petersen et al. 2004, Meyer et al. 2005, Rich et al. 2008). Two factors which regulate anammox are temperature for marine sediments, with greater anammox activity at lower temperatures relative to denitrification (Dalsgaard \& Thamdrup 2002, Rysgaard et al. 2004), and an in situ supply of $\mathrm{NO}_{2}{ }^{-}$ modulated by organic carbon and/or the concentration of $\mathrm{NO}_{3}{ }^{-}$in the overlying water column of estuarine (Trimmer et al. 2003, 2005, Meyer et al. 2005, RisgaardPetersen et al. 2005) and arctic marine sediments (Rysgaard et al. 2004).

A general increase in the significance of anammox to $\mathrm{N}_{2}$ production with increasing water depth has been shown for marine sediments (Thamdrup \& Dalsgaard 2002, Engström et al. 2005), which was hypothesized to be due to limitation of denitrification by reactive organic matter in deeper waters. In our first study of 
anammox in an estuarine environment (Thames estuary, UK; Trimmer et al. 2003), we showed a clear trend of increasing contribution of anammox to $\mathrm{N}_{2}(\mathrm{ra}, \%)$ with increasing organic carbon and $\mathrm{NO}_{3}{ }^{-}$further upstream. This pattern was in stark contrast with that reported for the coastal sediments, but since then has also been reported for the subtropical Logan-Albert estuary system in Australia (Meyer et al. 2005) and for parts of Chesapeake Bay (Rich et al. 2008). Meyer et al. (2005) were able to correlate the greater contribution of anammox to the production of $\mathrm{N}_{2}$ with a greater availability of $\mathrm{NO}_{2}^{-}$in the pore water. Together this corroborated a link between organic carbon and a supply of $\mathrm{NO}_{2}{ }^{-}$via $\mathrm{NO}_{3}{ }^{-}$reduction (Trimmer et al. 2003, Meyer et al. 2005). The importance of $\mathrm{NO}_{3}{ }^{-}$was confirmed by Risgaard-Petersen et al. (2004), who found no significant anammox activity in Norsminde Fjord but an ra of up to $22 \%$ in Randers Fjord; in Rander Fjord, $\mathrm{NO}_{3}^{-}$was abundant in the water column and penetrated into the sediment, but was absent in Nors- minde Fjord. Given the ubiquity of $\mathrm{NO}_{3}{ }^{-}$towards the landward end of UK estuaries, such limitation is unlikely (Nedwell et al. 2002).

The aim of the present study was to explore the distribution of anammox in the estuaries of southeast England and thus extend the knowledge of the biogeography of the anammox process in relation to the distribution of both organic carbon and water column $\mathrm{NO}_{3}^{-}$.

\section{MATERIALS AND METHODS}

Sample sites and screening for anammox. Samples of sediment (oxic and suboxic layers 0 to $2 \mathrm{~cm}$ ) and estuary water (filtered $0.2 \mu \mathrm{m}$ Minisart Plus ${ }^{\mathrm{TM}}$, Sartorius) were collected from intertidal flats at low tide from 40 sites over 9 estuaries in southeast England in summer 2004 (Fig. 1). Sediment samples were stored in plastic bags and returned to the laboratory as quickly

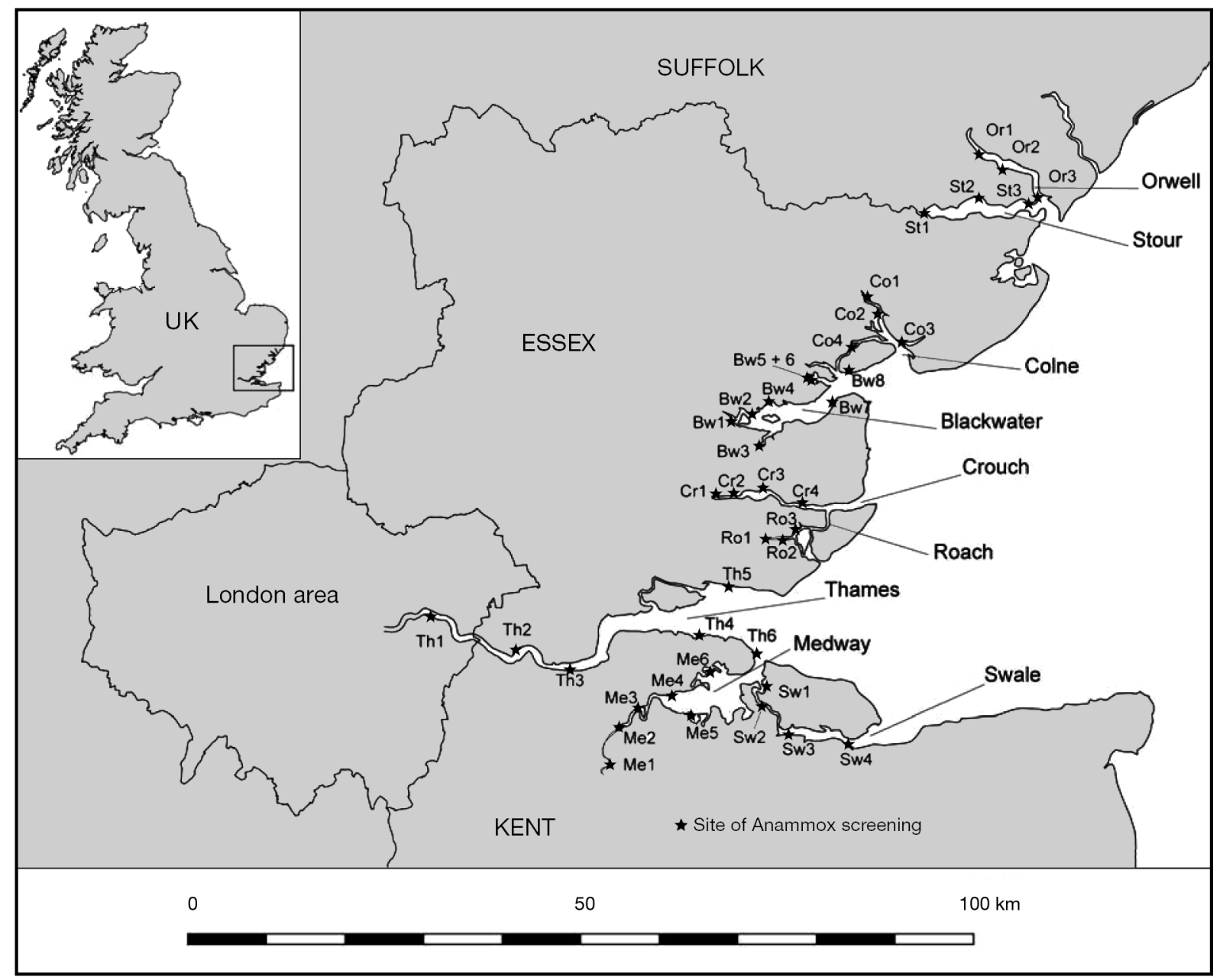

Fig. 1. Southeast England (inset on UK map), with sampling sites ( $\star$ ) and codes. The key to the site codes is given in Table 1 
as possible. Upon return to the laboratory, water samples were measured for salinity with a hand-held refractometer, then frozen at $-20^{\circ} \mathrm{C}$ until later nutrient analysis for $\mathrm{NO}_{3}{ }^{-}, \mathrm{NO}_{2}{ }^{-}$and $\mathrm{NH}_{4}{ }^{+}$(see section 'Analyses and calculations' below). A standardised experiment was used to assay the sediment for the anammox reaction using anaerobic sediment slurries as described previously (Trimmer et al. 2003). For each site, sediment slurries $(20 \mathrm{ml}$ homogenised sediment, plus $14 \mathrm{ml}$ of degassed low nutrient sea water [LNS] adjusted to in situ salinity with distilled water) were prepared and sealed in $37 \mathrm{ml}$ serum bottles (Alltech Associates) inside an anaerobic glove box (Belle Technologies). Slurries were preincubated on rollers in the dark in a constant temperature room at $15^{\circ} \mathrm{C}$ overnight to ensure that all traces of potential oxidants (e.g. $\mathrm{NO}_{3}{ }^{-}, \mathrm{NO}_{2}{ }^{-}$and $\mathrm{O}_{2}$ ) were removed prior to the start of any experiments.

Subsequently, the slurries were enriched by injection through the septa using microlitre syringes (Hamilton) with degassed concentrated stocks of either ${ }^{15} \mathrm{NH}_{4} \mathrm{Cl}\left(120 \mathrm{mM}{ }^{15} \mathrm{NH}_{4} \mathrm{Cl}\right.$ [99.3 ${ }^{15} \mathrm{~N}$ atom \%], SigmaAldrich) plus $\mathrm{Na}^{14} \mathrm{NO}_{3}$ (93 mM, VWR International) or ${ }^{14} \mathrm{NH}_{4} \mathrm{Cl}$ (120 mM ${ }^{14} \mathrm{NH}_{4} \mathrm{Cl}$, VWR International) plus $\mathrm{Na}^{15} \mathrm{NO}_{3}$ (93 mM [99.2 ${ }^{15} \mathrm{~N}$ atom \%], Sigma-Aldrich) to give a final concentration of $500 \mathrm{\mu M} \mathrm{NH}_{4}{ }^{+}$(in the case of ${ }^{15} \mathrm{NH}_{4}{ }^{+}$this represented an $\sim 60 \%$ labelling of the $\mathrm{NH}_{4}{ }^{+}$pool on average) and $100 \mathrm{MM} \mathrm{NO}_{3}{ }^{-}$or 0 in the case of controls. All of the slurries were then incubated overnight as above, after which samples of the headspace gas were collected $(1 \mathrm{ml})$ using a gas-tight syringe (SGE, gastight Luer-lock syringe, Alltech Associates) and stored in water-filled gas-tight vials (12 ml Exetainer, Labco). The ${ }^{15} \mathrm{~N}$-labelling of the $\mathrm{NH}_{4}{ }^{+}$ pool was estimated by the difference in pore water concentration of $\mathrm{NH}_{4}{ }^{+}$before (non-enriched reference) and after enrichment with ${ }^{15} \mathrm{~N}-\mathrm{NH}_{4}{ }^{+}$. Appropriate slurries were centrifuged, the supernatant filtered $(0.2 \mu \mathrm{m}$, Minisart Plus ${ }^{\mathrm{TM}}$, Sartorius) and then analysed for $\mathrm{NH}_{4}{ }^{+}$ (see section 'Analyses and calculations' below).

A relative measure of sediment reactivity. We have already shown that both anammox activity and its contribution to the production of $\mathrm{N}_{2}$ are correlated with the organic carbon content of the sediment (Trimmer et al. 2003). In the present study we wanted to test whether organic content was actually representative of reactivity across a broad range of sediment types. In a subsequent trip to the original anammox survey sites, a further $1 \mathrm{ml}$ of sediment was collected from the top $1 \mathrm{~cm}$ of sediment (using a truncated hypodermic syringe) at 5 positions (by proportion of exposed intertidal) on the intertidal flats at 10 of the original sites (4 Medway, 3 Stour and 3 Thames, i.e. where we had measured most of the highest ra values) and transferred to a gas-tight vial (as above). The 50 vials were then incubated at $22^{\circ} \mathrm{C}$ and the headspace of each was repeatedly sampled every $\sim 90 \mathrm{~min}$ for $83 \mathrm{~h}$ and analysed for $\mathrm{CO}_{2}$ by gas chromatography-flame ionization detection (GCFID) after catalytic reduction (hot nickel NiCat, Agilent Technologies) to $\mathrm{CH}_{4}$, as described in Sanders et al. (2007). Rates of $\mathrm{CO}_{2}$ production were calculated using linear regression as the change in amount of $\mathrm{CO}_{2}$ as a function of time. Subsequently, each vial was opened and the sediment dried to a constant weight and treated for analysis of organic carbon content as described in the section 'Analyses and calculations' below. A relative measure of sediment or organic carbon reactivity $(k)$ in terms of carbon turnover per unit time was calculated according to (Middelburg et al. 1996, Moodley et al. 2005):

$$
k=\frac{R}{C}
$$

where $R$ is the measured rate of $\mathrm{CO}_{2}$ produced per gram of dry sediment per day and $C$ the organic carbon content of the sediment $\left(\mu \mathrm{mol} \mathrm{C} \mathrm{g}^{-1}\right.$ dry sediment, which is not strictly a concentration). Hence the turnover of the carbon pool per day was represented by:

$$
k \mathrm{~d}^{-1}=\frac{\mu \mathrm{molCO}_{2 \text { prod }} \mathrm{g} \text { dry sed } \mathrm{dr}^{-1} \mathrm{~d}^{-1}}{\mu \mathrm{molC}_{\text {Org }} \mathrm{g} \text { dry sed }}
$$

In addition, we checked whether our measurement of the accumulation of $\mathrm{CO}_{2}$ in the headspace was representative of the majority of $\mathrm{CO}_{2}$ produced in the sediment, i.e. what fraction, if any, accumulated as $\mathrm{HCO}_{3}{ }^{-}$and $\mathrm{CO}_{3}{ }^{-}$. To do this we repeated the assay at the seaward and landward ends of the Medway estuary and compared the change in each respective pool over $76 \mathrm{~h}$. Twenty replicate $1 \mathrm{ml}$ samples of sediment were placed in gas-tight vials (12 $\mathrm{ml}$, as above) and the concentration of $\mathrm{CO}_{2}$ in the headspace was measured in half of them by GC-FID; the remainder were incubated for $76 \mathrm{~h}$. After measuring the initial $\mathrm{CO}_{2}$, the vials were centrifuged at ca. $1500 \times g$ for $3 \mathrm{~min}$, and a $100 \mu \mathrm{l}$ sample of pore water was collected and transferred to a smaller gas-tight vial $(3 \mathrm{ml})$; its $\mathrm{pH}$ was measured using a narrow tip probe (pHC4000-8, Radiometer Analytical). All the $3 \mathrm{ml}$ vials were then sealed and the headspaces sampled for $\mathrm{CO}_{2}$ as before. Subsequently, the $100 \mu$ of pore water was acidified $(\mathrm{pH}<0.8)$ by injecting $\mathrm{HCl}(100 \mu \mathrm{l}$ of $1 \mathrm{M})$ through each septa and the vials were then shaken vigorously for $2 \mathrm{~min}$ and allowed to equilibrate before again measuring the $\mathrm{CO}_{2}$ in the headspace. This procedure was repeated on the other half of the samples after $76 \mathrm{~h}$. At each point, the equilibration for $\mathrm{CO}_{2}$ between the headspace and the pore water in the sediment and that extracted $(100 \mu \mathrm{l})$ was calculated according to Weiss (1974). 
Analyses and calculations. All nutrient analyses $\left(\mathrm{NO}_{3}{ }^{-}, \mathrm{NO}_{2}{ }^{-}\right.$and $\left.\mathrm{NH}_{4}{ }^{+}\right)$were carried out using a continuous flow autoanalyser (Skalar, $\mathrm{SAN}^{++}$, De-Breda) and standard colorimetric techniques. Water content, bulk density and porosity were determined from the dry and wet weights of known volumes of sediment. Samples of this sediment were subsequently treated according to the methods of Hedges \& Stern (1984) before combustion in an elemental analyser, and analysis of organic carbon via a continuous flow-isotope ratio mass spectrometer (CF-IRMS) was standard- ised against known quantities of urea (Delta Matt Plus, Thermo-Finnigan). Samples of the headspace $(25 \mu l)$ from the gas-tight vials were injected using an autosampler into the elemental analyser interfaced with the CF-IRMS, and the mass to charge ratios for $\mathrm{m} / \mathrm{z} 28$, 29 and 30 nitrogen $\left({ }^{28} \mathrm{~N}_{2,}{ }^{29} \mathrm{~N}_{2}\right.$ and $\left.{ }^{30} \mathrm{~N}_{2}\right)$ were measured (Delta Matt Plus, Thermo-Finnigan). The total production of $\mathrm{N}_{2}$ due to either anammox (with ${ }^{15} \mathrm{NH}_{4}{ }^{+}$ and $\left.{ }^{15} \mathrm{NO}_{3}{ }^{-}\right)$or denitrification $\left({ }^{15} \mathrm{NO}_{3}{ }^{-}\right)$was calculated as described previously (Thamdrup \& Dalsgaard 2002, Trimmer et al. 2003). Note that here we did not mea-

Table 1. Estuaries where sediment was assayed for the anammox reaction, water column (salinity, $\mathrm{NO}_{3}{ }^{-}$) and sediment (porosity, organic carbon) characteristics and the potential contribution of anammox to the production of $\mathrm{N}_{2}$ gas ( $r a$, \%). Code: refers to the sites in Fig. 1; blank cells: samples inadvertently lost before analysis

\begin{tabular}{|c|c|c|c|c|c|c|c|}
\hline Estuary & Site & Code & Salinity & $\begin{array}{l}\mathrm{NO}_{3}^{-} \\
(\mu \mathrm{M})\end{array}$ & Porosity & $\begin{array}{l}\text { Organic C } \\
\text { (\% dry wt) }\end{array}$ & $\begin{array}{c}\text { Anammox } \\
(r a, \%)\end{array}$ \\
\hline \multirow[t]{5}{*}{ Thames } & Grays & Th2 & 19 & 317 & 0.82 & 2.38 & 7.44 \\
\hline & Grays & Th2 & 17 & 314 & 0.82 & 1.99 & 5.01 \\
\hline & Gravesend & Th3 & 21 & 261 & & 1.82 & 7.06 \\
\hline & Southend & Th5 & 33 & 23 & 0.62 & 0.77 & 1.45 \\
\hline & Southend & Th5 & 34 & 37 & 0.59 & 0.41 & 1.76 \\
\hline \multirow[t]{5}{*}{ Medway } & Wouldham & Me1 & 5 & 340 & 0.83 & 2.39 & 7.48 \\
\hline & Strood & $\mathrm{Me} 3$ & 5 & 216 & 0.73 & 2.01 & 10.93 \\
\hline & Hoo & $\mathrm{Me} 4$ & 29 & 16 & 0.68 & 1.92 & 4.49 \\
\hline & Horrid Hill & Me5 & 34 & 31 & 0.70 & 1.03 & 3.09 \\
\hline & Stoke & Me6 & 25 & 7 & 0.88 & 2.57 & 5.39 \\
\hline \multirow[t]{4}{*}{ Swale } & Queenborough & Sw1 & 24 & 65 & 0.80 & 1.30 & 2.41 \\
\hline & Kingsferry & Sw2 & 20 & 66 & 0.77 & 1.04 & 1.57 \\
\hline & Saxon Way & Sw3 & 30 & 40 & 0.79 & 1.31 & 2.31 \\
\hline & Harty Ferry (S) & Sw4 & 32 & 87 & 0.77 & 1.89 & 1.74 \\
\hline \multirow[t]{3}{*}{ Roach } & Broomhills & Ro1 & 5 & 183 & 0.77 & & 1.90 \\
\hline & Bolts Farm & Ro2 & 21.5 & 54 & 0.70 & & 0.57 \\
\hline & Paglesham & Ro3 & 23 & 36 & 0.65 & & 1.13 \\
\hline \multirow[t]{4}{*}{ Crouch } & Clementsgreen & $\mathrm{Cr} 1$ & 23 & 36 & 0.83 & 1.77 & 2.92 \\
\hline & Fambridge & $\mathrm{Cr} 2$ & 31 & 44 & 0.79 & 1.09 & 1.37 \\
\hline & Althorne & $\mathrm{Cr} 3$ & 33 & 55 & 0.79 & 0.96 & 1.64 \\
\hline & Burnham & $\mathrm{Cr} 4$ & 35 & 20 & 0.76 & 0.93 & 2.48 \\
\hline \multirow[t]{8}{*}{ Blackwater } & Maldon & Bw1 & 31 & 109 & 0.82 & 2.06 & 7.32 \\
\hline & Decoy Point & Bw2 & 34.5 & 106 & 0.73 & 2.05 & 1.97 \\
\hline & Maylandsea & Bw3 & 34.5 & 13 & 0.66 & 1.26 & 1.86 \\
\hline & Goldhanger & Bw4 & 34.5 & 9 & 0.72 & 1.15 & 0.69 \\
\hline & Tollesbury & Bw5 & 34.5 & 3 & 0.83 & 1.21 & 0.45 \\
\hline & Tollesbury & Bw6 & 34.5 & 6 & 0.78 & 3.25 & 0.76 \\
\hline & Bradwell & Bw7 & 34.5 & 29 & 0.74 & 1.64 & 1.72 \\
\hline & West Mersea & Bw8 & 34.5 & 29 & 0.77 & 1.50 & 1.72 \\
\hline \multirow[t]{5}{*}{ Colne } & The Hythe & Co1 & 1 & 719 & 0.80 & 1.78 & 7.85 \\
\hline & Wivenhoe & $\mathrm{Co} 2$ & 28 & 212 & 0.81 & 1.51 & 7.56 \\
\hline & The Ford & $\mathrm{Co} 3$ & 26 & 211 & 0.74 & 1.41 & 5.30 \\
\hline & The Strood & $\mathrm{Co} 4$ & 32 & 62 & 0.80 & 1.65 & 1.07 \\
\hline & Brightlingsea & Co5 & 34.5 & 67 & 0.58 & 0.59 & 0.70 \\
\hline \multirow[t]{3}{*}{ Stour } & Sluice & St1 & 1 & 790 & 0.75 & 2.32 & 8.03 \\
\hline & Holbrook & St2 & 3 & 612 & 0.78 & 2.09 & 1.55 \\
\hline & Shotley Gate & St3 & 34.5 & 99 & 0.75 & 1.06 & 2.46 \\
\hline \multirow{3}{*}{ Orwell } & Orwell Bridge & Or1 & 31 & 44 & 0.78 & 2.18 & 3.06 \\
\hline & Butt \& Oyster & Or2 & 32 & 167 & 0.82 & 1.17 & 3.57 \\
\hline & Shotley Gate & Or3 & 34.5 & 78 & 0.57 & 0.41 & 0.89 \\
\hline
\end{tabular}


sure actual rates or the specific activity of $\mathrm{N}_{2}$ production by either anammox or denitrification but merely their respective yields of $\mathrm{N}_{2}$ from the total reduction of either $\sim 116 \mathrm{nmol}$ of ${ }^{14} \mathrm{~N}$ - or ${ }^{15} \mathrm{~N}-\mathrm{NO}_{3}{ }^{-} \mathrm{ml}^{-1}$ of wet sediment after incubating to completion (RisgaardPetersen et al. 2004). The relative yield of $\mathrm{N}_{2}$ due to anammox was then expressed as percentage of the total yield (ra). All statistical analyses were performed using SPSS version 15, and any data which were not normally distributed were first $\log _{10}$-transformed before any relationships between potential controlling variables (e.g. $\mathrm{NO}_{3}{ }^{-}$and organic carbon) and anammox or reactivity were explored, using Pearson productmoment and partial correlation or linear regression where appropriate.

\section{RESULTS}

\section{Anammox potential}

The anammox reaction was found at all 40 sites assayed across the 9 estuaries, with the potential contribution of anammox to $\mathrm{N}_{2}$ production ranging from $<1 \%$ (at only 5 sites) to $11 \%$ (Table 1 ). There were strong axial gradients of $\mathrm{NO}_{3}^{-}$and organic carbon along the estuaries, with both typically negatively correlated with salinity $(\mathrm{r}=-0.673$ and $-0.373, \mathrm{p}<0.001$, 0.023 and $n=40$ and 37 , respectively; data not shown). The anammox potential was positively correlated with both the organic carbon content of the sediment and the concentration of $\mathrm{NO}_{3}{ }^{-}$in the overlying water across all of the estuaries (Fig. 2A,B). Further exploration of
Table 2. Pearson and partial correlation analyses on log-transformed data between anammox $(r a, \%)$ and water column $\mathrm{NO}_{3}{ }^{-}$, salinity or sedimentary organic carbon. cv: controlling variable

\begin{tabular}{|lccc|}
\hline & $\begin{array}{c}\mathrm{NO}_{3}{ }^{-} \\
(\mu \mathrm{M})\end{array}$ & Salinity & $\begin{array}{c}\text { Organic C } \\
(\% \text { dry wt })\end{array}$ \\
\hline $\begin{array}{l}\text { Pearson correlation } \\
\text { coefficient }(\mathrm{r})\end{array}$ & 0.621 & -0.499 & 0.479 \\
$\mathrm{p}$ & 0.000 & 0.003 & 0.002 \\
$\begin{array}{l}\text { Partial correlation } \\
\text { coefficient (r) }\end{array}$ & 0.505 & $\mathrm{cV}$ & $\mathrm{cv}$ \\
$\mathrm{p}$ & 0.002 & & \\
$\begin{array}{l}\text { Partial correlation } \\
\text { coefficient (r) }\end{array}$ & $\mathrm{cV}$ & $\mathrm{cV}$ & 0.440 \\
$\mathrm{p}$ & & & 0.008 \\
\hline
\end{tabular}

the data, using partial correlation to control for organic carbon, nitrate and salinity, in turn suggested that the relationships between anammox, organic carbon and nitrate were both significant, though the relationship with $\mathrm{NO}_{3}{ }^{-}$was stronger than that for organic carbon (Table 2).

We used both the ${ }^{15} \mathrm{NH}_{4}{ }^{+}$and ${ }^{15} \mathrm{NO}_{3}{ }^{-}$assays to screen sediment for the anammox reaction, with the latter used to directly estimate the respective contributions from either anammox or denitrification to the production of $\mathrm{N}_{2}$ (ra). It is important to bear in mind that our data represent a relative yield of $\mathrm{N}_{2}$ after complete reduction of a known amount of $\mathrm{NO}_{3}^{-}\left(\sim 116 \mathrm{nmol} \mathrm{ml}^{-1}\right.$ wet sediment) and not a rate. Above $2 \mathrm{nmol} \mathrm{N}_{2} \mathrm{ml}^{-1}$ wet sediment (i.e. $r a>3.4 \% ;[2 /(116 / 2)] \times 100)$ there
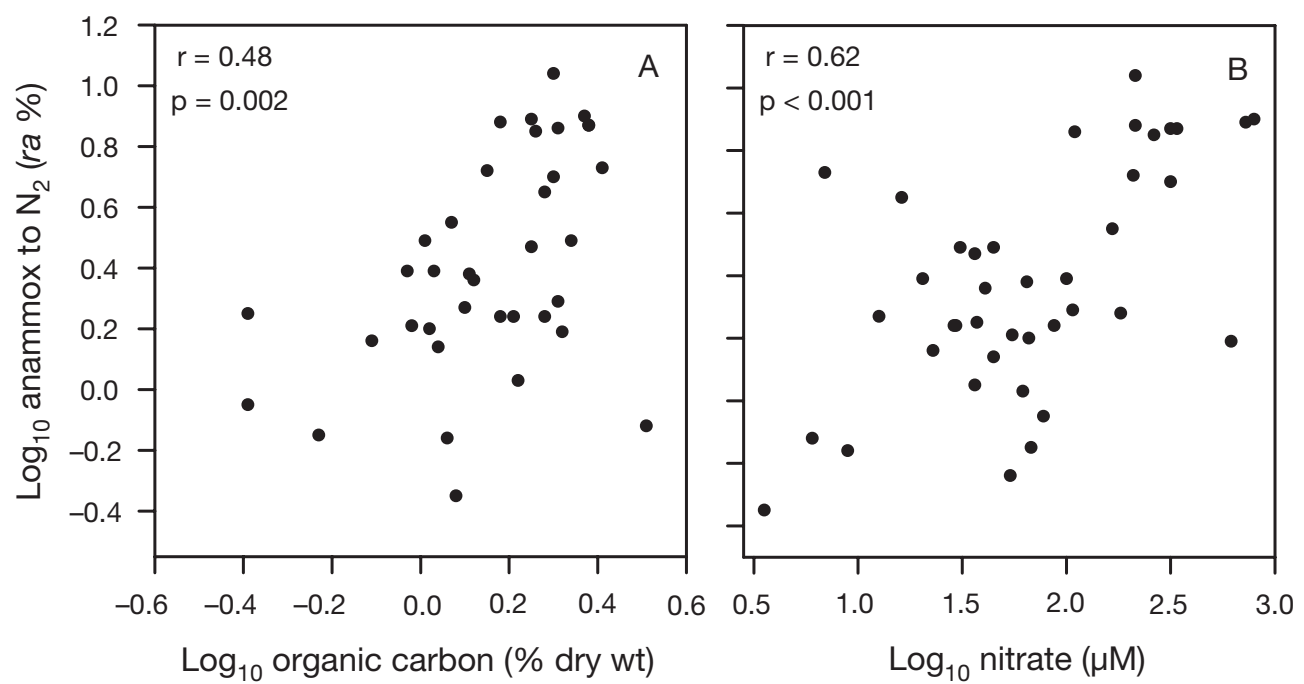

Fig. 2. Potential contribution of anammox to $\mathrm{N}_{2}$ production ( $\mathrm{ra}, \%$ ) scattered against (A) the organic carbon content of the sediment and (B) the concentration of nitrate in the overlying water, all as $\log _{10}$-transformed data. The correlation coefficient $r$ and its significance $\mathrm{p}$ are also shown. Partial correlations are given in Table 2 
was good agreement between the 2 assays, but it was clear that ${ }^{15} \mathrm{NO}_{3}{ }^{-}$was more sensitive than ${ }^{15} \mathrm{NH}_{4}{ }^{+}$at the lower yields for anammox (Fig. 3A). Although it was still possible to detect anammox with ${ }^{15} \mathrm{NH}_{4}{ }^{+}$below a yield of $2 \mathrm{nmol} \mathrm{N}_{2}$, the slope was much shallower and would underestimate the potential for anammox by $\sim 8$-fold relative to ${ }^{15} \mathrm{NO}_{3}{ }^{-}$. It is worth noting that not all of the ${ }^{15} \mathrm{~N}$ from ${ }^{15} \mathrm{NO}_{3}{ }^{-}$was recovered as ${ }^{15} \mathrm{~N}$ gas (range $=11$ to $68 \%$, mean $=34 \pm 2, \mathrm{n}=40$ ) and this loss could be indicative of considerable dissimilatory
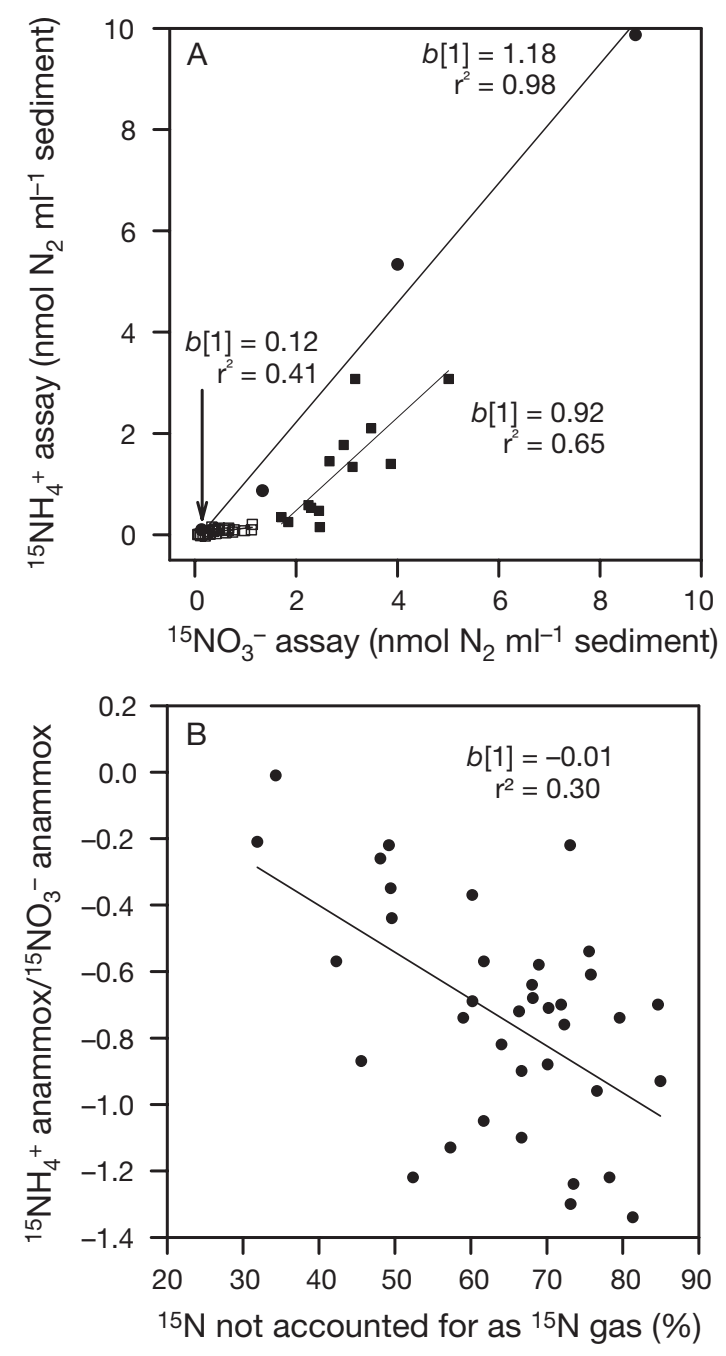

Fig. 3. Comparison between the 2 assays for measuring anammox. (A) Estimate of total anammox yield (nmol $\mathrm{N}_{2} \mathrm{ml}^{-1}$ wet sediment) measured with the ${ }^{15} \mathrm{NH}_{4}{ }^{+}$assay as a function of the yield measured with ${ }^{15} \mathrm{NO}_{3}{ }^{-}$. ( $)$: data from our original survey of the Thames estuary (Trimmer et al. 2003); $(\square, \mathbf{\square})$ : data from the present study split between yields of approximately $\leq 2$ and $\geq 2 \mathrm{nmol} \mathrm{N}_{2} \mathrm{ml}^{-1}$ wet sediment, respectively. (B) Ratio of anammox yield with ${ }^{15} \mathrm{NH}_{4}{ }^{+}$to ${ }^{15} \mathrm{NO}_{3}{ }^{-}$as a function of the amount of ${ }^{15} \mathrm{~N}$ not accounted for as ${ }^{15} \mathrm{~N}$ gas (\%). The regression coefficient $\left(\mathrm{r}^{2}\right)$ and slope $(b[1])$ of each line is indicated; $\mathrm{p}<0.05$ in each case reduction of $\mathrm{NO}_{3}{ }^{-}$to ammonium (DNRA) in the slurries. Further, this loss of gas (be it ${ }^{15} \mathrm{~N}_{2}$ or its analogue, ${ }^{14} \mathrm{~N}_{2}$ ) could explain some of the change in the ratio of anammox measured with ${ }^{15} \mathrm{NH}_{4}{ }^{+}$relative to that measured with ${ }^{15} \mathrm{NO}_{3}^{-}$(Fig. 3B).
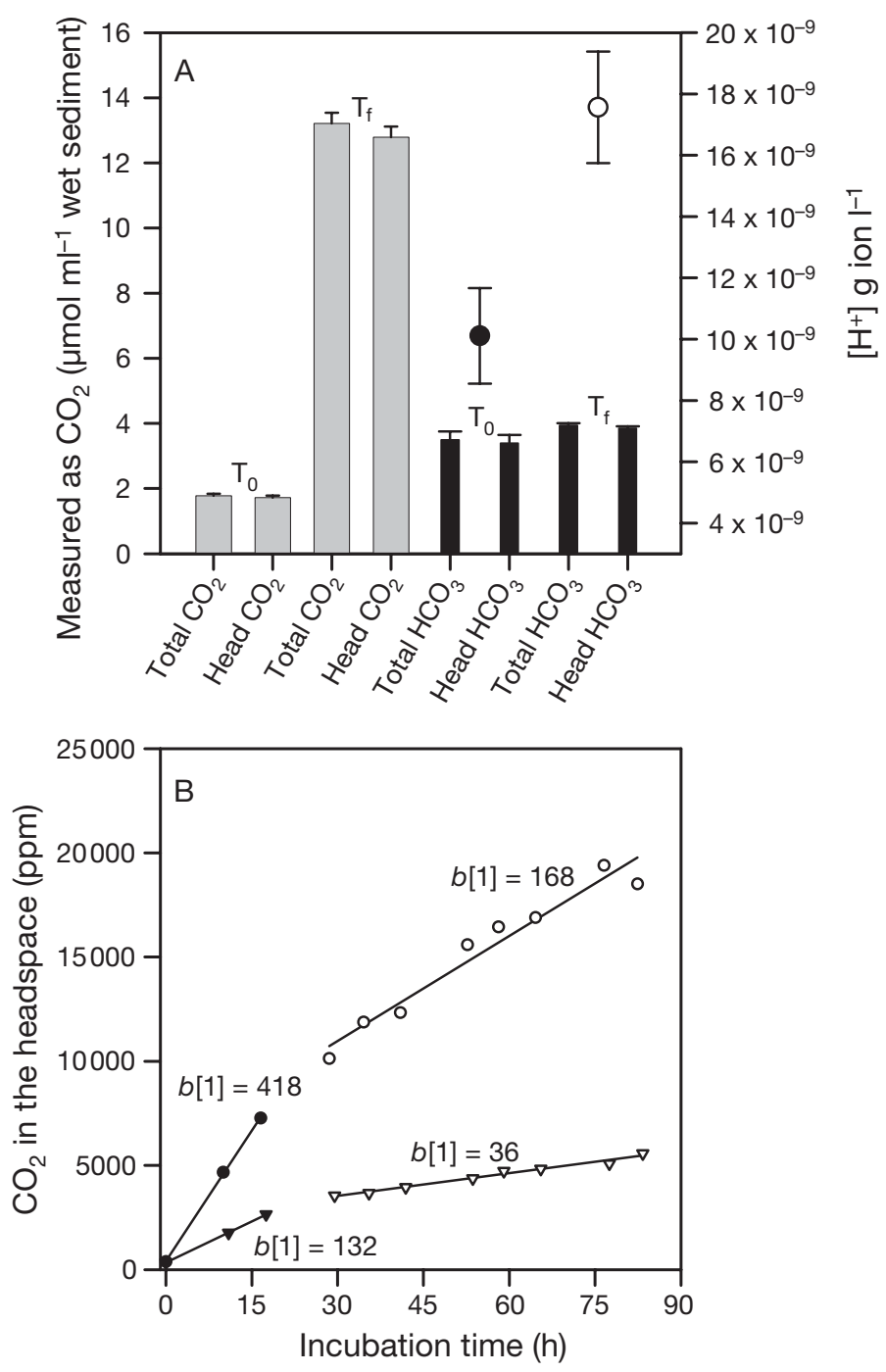

Fig. 4. Testing the simple assay for sediment reactivity. (A) Inventory of $\mathrm{CO}_{2}$ as that measured directly as $\mathrm{CO}_{2}$ (grey bars) in the head space (head $\mathrm{CO}_{2}$ ) plus that dissolved $\left(\mathrm{as} \mathrm{CO}_{2}\right)$ in the pore water (total $\mathrm{CO}_{2}$ ) and that in $100 \mu \mathrm{l}$ of pore water after acidification (black bars), again as $\mathrm{CO}_{2}$ in the headspace (head $\mathrm{HCO}_{3}$ ) plus that dissolved in the $100 \mu \mathrm{l}$ of pore water (total $\left.\mathrm{HCO}_{3}\right)$. The initial $\left(\mathrm{T}_{0}\right)$ and final $\left(\mathrm{T}_{\mathrm{f}}\right)$ amounts of $\mathrm{CO}_{2}$ after $76 \mathrm{~h}$ are indicated, as is the increase in $\mathrm{H}^{+}$ions in the pore water (decrease in $\mathrm{pH}$ ) over the same period $(\bullet, 0)$. Data are from the seaward site of the Medway estuary $(n=10$, $\pm \mathrm{SE}$ ). (B) Evolution of $\mathrm{CO}_{2}$ from the sediment into the headspace of the gas-tight vials for the most $(\bullet, 0)$ and least $(\boldsymbol{\nabla}, \nabla)$ active sediment, with closed and open symbols representing data during and after the first $16 \mathrm{~h}$ of incubation, respectively. Note the marked change in rate (slope, $b[1]$ ) after $16 h_{\text {; the }}$ steady evolution over the subsequent $2 \mathrm{~d}$ was used to estimate rates of $\mathrm{CO}_{2}$ production 

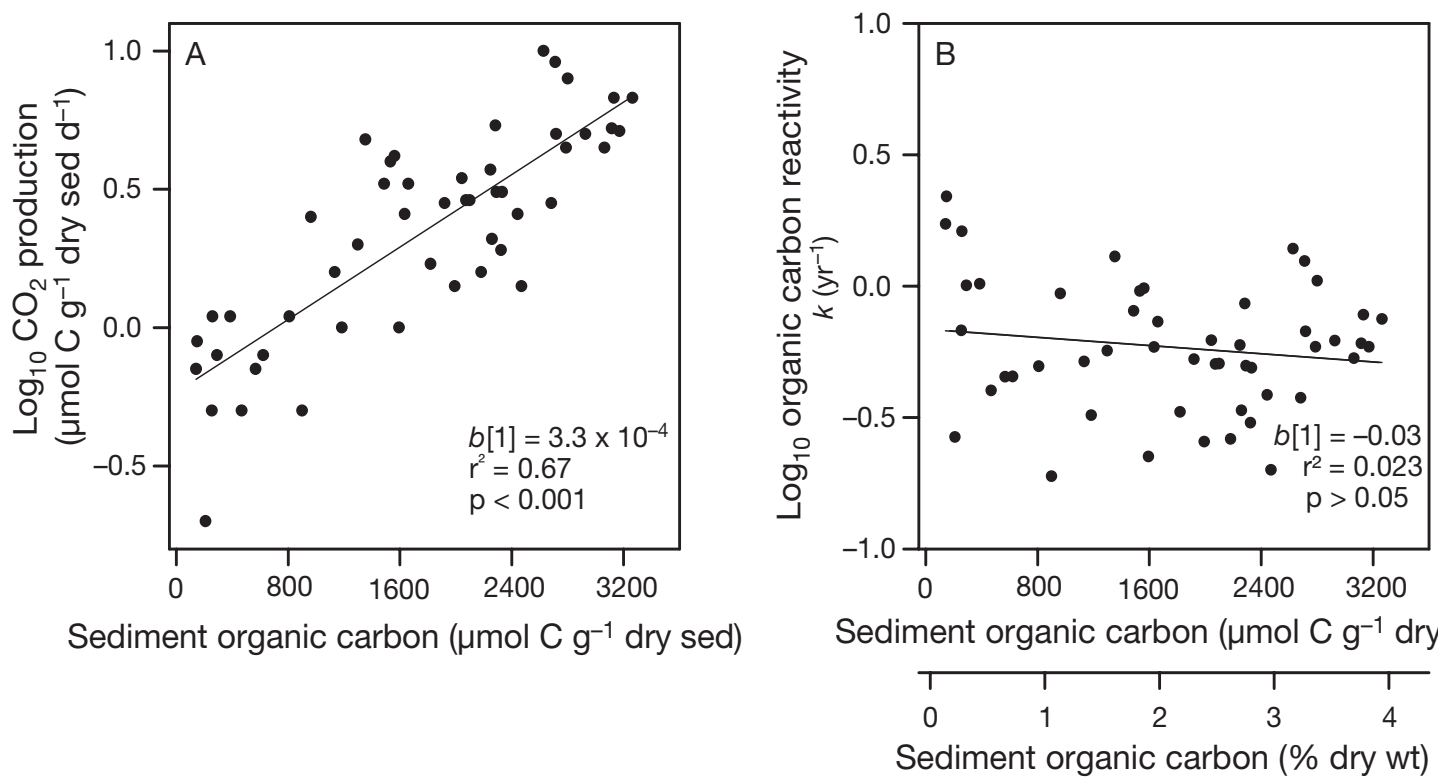

Fig. 5. Relative reactivity of organic carbon at a subsample of 10 of the original survey sites. (A) Production of $\mathrm{CO}_{2}$ as a function of the organic carbon content of the sediment and (B) the product of these as an estimate of reactivity, $k$ (here scaled to turnovers $\mathrm{yr}^{-1}$ to make it more readily comparable to other datasets). The $\mathrm{x}$-axis is given in terms of molar amounts and percent for comparison. The regression coefficient $\left(\mathrm{r}^{2}\right)$, slope $(b[1])$ and $\mathrm{p}$-value is indicated in each case

\section{Organic reactivity}

At each stage of the reactivity assay the vast majority $\left(\geq 96 \%\right.$ ) of the $\mathrm{CO}_{2}$ was recovered directly in the headspace (Fig. 4A, head versus total). In addition, at both the landward and seaward end of the Medway estuary, the vast majority of the measured flux ( $\geq 96 \%$ ) of total dissolved inorganic carbon $\left(\mathrm{CO}_{2}, \mathrm{HCO}_{3}^{-}\right.$and $\left.\mathrm{CO}_{3}{ }^{-}\right)$ was also measured directly as an accumulation of $\mathrm{CO}_{2}$ gas in the headspace (Fig. 4A, seaward site only), with the small difference in the dissociated pool between $\mathrm{T}_{0}$ (initial time) and $\mathrm{T}_{\mathrm{f}}$ (final time; $76 \mathrm{~h}$ ) not significant $(\mathrm{p}>$ 0.05). There was also a marked decrease in the $\mathrm{pH}$ of the pore water over the $76 \mathrm{~h}$, depicted here as a significant increase in the average $\mathrm{H}^{+}$concentration. The release of $\mathrm{CO}_{2}$ from the sediment was almost twice as great in the first $16 \mathrm{~h}$ of incubation compared to that in the remaining $55 \mathrm{~h}$ (Fig. 4B), and we used the second half of the time series to estimate the rates of $\mathrm{CO}_{2}$ production.

Production of $\mathrm{CO}_{2}$ by the sediment (at a subsample of 10 of the original sites) ranged from 0.2 to $10 \mu \mathrm{mol}$ $\mathrm{CO}_{2} \mathrm{~g}^{-1}$ dry sediment $\mathrm{d}^{-1}\left(\log _{10} \mathrm{CO}_{2 \text { prod }}=-0.7\right.$ to 1 ; Fig. 5A), with the rate increasing as a function of the organic carbon content of the sediment. As a consequence of this approximately linear relationship, the reactivity (or rate of turnover of organic carbon) was found to be approximately constant across all of the sites at $0.6 \mathrm{yr}^{-1}\left( \pm 95 \% \mathrm{CI}=0.5\right.$ to $0.7 \mathrm{yr}^{-1}, \log _{10} \mathrm{k}=$ -0.23 ; Fig. 5B).

\section{DISCUSSION}

Here we have demonstrated quite clearly that the potential for the anammox reaction is widespread in the estuaries of southeast England, but it is important to appreciate that the significance of anammox to the production of $\mathrm{N}_{2}$ is likely to be both seasonal and potentially even greater in intact sediment cores (Trimmer et al. 2005, 2006). The simple trend in decreasing anammox contribution to $\mathrm{N}_{2}$ production from the land to the sea found in the Thames (UK) and the LoganAlbert (Australia) estuarine systems was not observed within all the estuaries studied here, and this probably reflects differences in the morphologies of the estuaries sampled (Trimmer et al. 2003, Meyer et al. 2005, Rich et al. 2008). For example, the Thames and LoganAlbert estuaries are classic coastal plain estuaries, with clear axial gradients in $\mathrm{NO}_{3}{ }^{-}$and probably also organic carbon in the sediment, whereas the Swale and Blackwater estuaries are more complex (Fig. 1, Table 1).

Despite these differences in estuarine morphology, taken across all 9 of the estuaries, the data suggest that the anammox potential was positively related to both $\mathrm{NO}_{3}{ }^{-}$in the overlying water and the organic carbon content of the sediment (Table 2). Although these are only observational data, the maintenance of an anammox potential by both $\mathrm{NO}_{3}{ }^{-}$and organic carbon is both logical and consistent with previous data for estuarine sediments (Trimmer et al. 2003, Risgaard-Petersen et al. 2004, Meyer et al. 2005, Rich et al. 2008). For exam- 
ple, it is well established that anammox is reliant on a supply of $\mathrm{NO}_{2}^{-}$to fuel the oxidation of $\mathrm{NH}_{4}{ }^{+}$and that this $\mathrm{NO}_{2}^{-}$is produced within the suboxic sediment by the reduction of $\mathrm{NO}_{3}^{-}$(Meyer et al. 2005). Further, Risgaard-Petersen et al. (2005) demonstrated that decreasing the concentration of $\mathrm{NO}_{3}{ }^{-}$in the overlying water from $600 \mu \mathrm{M}$ to $5-10 \mu \mathrm{M}$ reduced the sediment's capacity for anammox by $85 \%$. In turn, the heterotrophic reduction of $\mathrm{NO}_{3}{ }^{-}$to $\mathrm{NO}_{2}{ }^{-}$cannot proceed without a source of electron donors. Hence, in the present study, the greatest potential for anammox was predominantly measured in the upper reaches of the estuaries, where the organic carbon content of the sediment and concentration of $\mathrm{NO}_{3}{ }^{-}$in the overlying water were both greatest, and, together, could maintain the critical supply of $\mathrm{NO}_{2}^{-}$. Although others have shown the contribution of anammox to $\mathrm{N}_{2}$ production to be independent of the concentration of $\mathrm{NO}_{2}^{-}$(Thamdrup \& Dalsgaard 2002, Dalsgaard \& Thamdrup 2002), the overall supply of $\mathrm{NO}_{2}{ }^{-}$regulates the overall amount of anammox (Meyer et al. 2005, Trimmer et al. 2005).

Interestingly, our simple assay for comparing the reactivity of organic carbon along the estuarine gradient suggested that reactivity was approximately constant $\left(\sim 0.6 \mathrm{yr}^{-1}\right)$. Such high and uniform reactivity across 3 of our estuarine systems suggested that the organic carbon was only a couple of months old (Middelburg 1989). Middelburg et al. (1996) reported an exponential drop in reactivity between salinities of 1 and 10 in the Westerscheldt estuary, but $k$ was approximately uniform seaward of these sites. At their upper sites, however, the total flux of $\mathrm{C}$ gas $\left(\mathrm{CO}_{2}+\mathrm{CH}_{4}\right)$ was dominated by methanogenesis, which was not the case at any of our sites. In the estuaries sampled in the present study, if the reactivity of the organic carbon was constant, then the increase in $\mathrm{CO}_{2}$ production, as a function of organic carbon content, could be linked to a greater abundance of bacteria supported by a greater availability of organic carbon. This supports the idea that it is the total availability of organic carbon, rather than its quality, coupled to a supply of $\mathrm{NO}_{3}^{-}$, which maintains the potential of a sediment to support the anammox reaction in these estuaries.

We used both ${ }^{15} \mathrm{NH}_{4}{ }^{+}$and ${ }^{15} \mathrm{NO}_{3}{ }^{-}$to assay for the anammox reaction. Whereas only ${ }^{15} \mathrm{NO}_{3}{ }^{-}$can be used to directly calculate $r a$, both assays should give similar estimates for total anammox (Thamdrup and Dalsgaard 2002, Trimmer et al. 2003), although others have not always found this to be the case (Rich et al. 2008). We found good agreement between the 2 assays (in line with our initial findings; Trimmer et al. 2003) for ra $>3 \%$, but a marked decrease in anammox measured with ${ }^{15} \mathrm{NH}_{4}{ }^{+}$relative to that for ${ }^{15} \mathrm{NO}_{3}{ }^{-}$at $\mathrm{ra}<3 \%$ (2 nmol N $\mathrm{m}_{i}^{-1}$ wet sediment, Fig. 3A,B). Some of this difference can be explained by simple probability. The chance of anammox making ${ }^{29} \mathrm{~N}_{2}$ in the presence of ${ }^{15} \mathrm{NO}_{3}{ }^{-}$and ${ }^{14} \mathrm{NH}_{4}{ }^{+}$is $100 \%$, i.e. all of the $\mathrm{NH}_{4}{ }^{+}$in the sediment pool can combine with ${ }^{15} \mathrm{NO}_{3}{ }^{-}$to make ${ }^{29} \mathrm{~N}_{2}$. In contrast, with ${ }^{15} \mathrm{NH}_{4}{ }^{+}$, only 30 to $80 \%$ of the $\mathrm{NH}_{4}{ }^{+}$ can combine with ${ }^{14} \mathrm{NO}_{3}{ }^{-}$to produce ${ }^{29} \mathrm{~N}_{2}$, and this ${ }^{15} \mathrm{~N}$ labelling of the $\mathrm{NH}_{4}{ }^{+}$pool will be further diluted by ammonification during the incubation. In addition, the ratio of ${ }^{15} \mathrm{NH}_{4}{ }^{+}$anammox to ${ }^{15} \mathrm{NO}_{3}{ }^{-}$anammox decreased with the decrease in the recovery of ${ }^{15} \mathrm{~N}$ gas (Fig. 4B), which would have exacerbated the decreased sensitivity of the ${ }^{15} \mathrm{NH}_{4}{ }^{+}$assay at the lower yields for anammox. If this loss of ${ }^{15} \mathrm{~N}$ added as ${ }^{15} \mathrm{NO}_{3}{ }^{-}$ was indicative of DNRA (though it may be an artefact of sediment slurries; Revsbech et al. 2006), then this could potentially complicate the measurement of anammox with ${ }^{15} \mathrm{NO}_{3}{ }^{-}$. The problem arises from the potential production of ${ }^{15} \mathrm{NH}_{4}{ }^{+}$from ${ }^{15} \mathrm{NO}_{3}{ }^{-}$via DNRA which could then, in the presence of anammox, combine with ${ }^{15} \mathrm{NO}_{2}{ }^{-}$to form $\mathrm{A}^{30} \mathrm{~N}_{2}$. The central tenet for the calculation of anammox is that denitrification is the only source of ${ }^{30} \mathrm{~N}_{2}$ and that $\mathrm{P}^{30} \mathrm{~N}_{2}=\mathrm{D}^{30} \mathrm{~N}_{2}$ (Thamdrup $\&$ Dalsgaard 2002). It should be clear that spurious production of $\mathrm{A}^{30} \mathrm{~N}_{2}$ would undermine this, though the chances of this appear slight. The probability of $\mathrm{A}^{30} \mathrm{~N}_{2}$ in 100 units of $\mathrm{N}_{2}$ is given by $\mathrm{A}^{30} \mathrm{~N}_{2}=100 \times r a \times q \times s$, where $q$ is the proportion of ${ }^{15} \mathrm{~N}$ in the $\mathrm{NO}_{3}{ }^{-}$pool (in our case 0.992) and $s$ the ${ }^{15} \mathrm{~N}$ in the $\mathrm{NH}_{4}{ }^{+}$pool. Our average amount of missing ${ }^{15} \mathrm{NO}_{3}{ }^{-}$was $62 \mu \mathrm{M}$ and our starting pool of ${ }^{14} \mathrm{NH}_{4}{ }^{+}$was $364 \mu \mathrm{M}$. If we assume a maximum ra in slurries of $10 \%$ (checked with ${ }^{15} \mathrm{NH}_{4}{ }^{+}$ which is not interfered with) then $\mathrm{A}^{30} \mathrm{~N}_{2}=100 \times 0.1 \times$ $0.992 \times 0.145$, or $1.4 \%$, which is not likely to cause any serious interference with the assumption that $\mathrm{P}^{30} \mathrm{~N}_{2}=$ $\mathrm{D}^{30} \mathrm{~N}_{2}$.

\section{CONCLUSIONS}

The present study provides firm evidence that the anammox metabolism is widespread in estuarine sediments and that its significance is associated with both high $\mathrm{NO}_{3}{ }^{-}$in the overlying water and a greater availability of organic carbon, which, in turn, could regulate the supply of $\mathrm{NO}_{2}^{-}$via the reduction of $\mathrm{NO}_{3}{ }^{-}$.

Acknowledgements. We thank I. A. Sanders for help with field work and analysis. This research has been supported by a Natural Environment Research Council grant (NER/A/S/ 2003/003) to M.T.

\section{LITERATURE CITED}

Dalsgaard T, Thamdrup B (2002) Factors controlling anaerobic ammonium oxidation with nitrite in marine sediments. Appl Environ Microbiol 68:3802-3808 
Dalsgaard T, Thamdrup B, Canfield DE (2005) Anaerobic ammonium oxidation (anammox) in the marine environment. Res Microbiol 156:457-464

Engström P, Dalsgaard T, Hulth S, Aller RC (2005) Anaerobic ammonium oxidation by nitrite (anammox): implications for $\mathrm{N}_{2}$ production in coastal marine sediments. Geochim Cosmochim Acta 69:2057-2065

Hedges JI, Stern JH (1984) Carbon and nitrogen determination of carbonate-containing solids. Limnol Oceanogr 29:657-663

Meyer RL, Risgaard-Petersen N, Allen DE (2005) Correlation between anammox activity and microscale distribution of nitrite in a subtropical mangrove sediment. Appl Environ Microbiol 71:6142-6149

Middelburg JJ (1989) A simple rate model for organic matter decomposition in marine sediments. Geochim Cosmochim Acta 53:1577-1581

Middelburg JJ, Klaver G, Nieuwenhuize J, Wielemaker A, de Haas W, Vlug T, van der Nat JFWA (1996) Organic matter mineralization in intertidal sediments along an estuarine gradient. Mar Ecol Prog Ser 132:157-168

Moodley L, Middelburg JJ, Herman PMJ, Soetart K, de Lange GJ (2005) Oxygenation and organic-matter preservation in marine sediments: direct experimental evidence from ancient organic carbon-rich deposits. Geology 33:889-892

Mulder A, van de Graaf AA, Robertson LA, Kuenen JG (1995) Anaerobic ammonium oxidation discovered in a denitrifying fluidized bed reactor. FEMS Microbiol Ecol 16:177-184

Nedwell DB, Dong LF, Sage A, Underwood GJC (2002) Variations of the nutrients loads to the mainland UK estuaries: correlation with catchment areas, urbanization and coastal eutrophication. Estuar Coast Shelf Sci 54:951-970

Revsbech NP, Risgaard-Petersen N, Schramm A, Nielsen LP (2006) Nitrogen transformations in stratified aquatic microbial ecosystems. Antonie Leeuwenhoek 90:361-375

Rich JJ, Dale OR, Song B, Ward BB (2008) Anaerobic ammonium oxidation in Chesapeake Bay sediments. Microb Ecol 55:311-320

Editorial responsibility: Patricia Glibert, Cambridge, Maryland, USA
Risgaard-Peterson N, Meyer RL, Schmid M, Jetten MSM, Enrich-Prast A, Rysgaard S, Revsbech NP (2004) Anaerobic ammonium oxidation in an estuarine sediment. Aquat Microb Ecol 36:293-304

Risgaard-Peterson N, Meyer RL, Revsbech NP (2005) Denitrification and anaerobic ammonium oxidation in sediments: effects of microphytobenthos and $\mathrm{NO}_{3}{ }^{-}$. Aquat Microb Ecol 40:67-76

Rysgaard S, Glud RN, Risgaard-Petersen N, Dalsgaard T (2004) Denitrification and anammox activity in Arctic marine sediments. Limnol Oceanogr 49:1493-1502

Sanders IA, Heppell CM, Cotton JA, Wharton G, Hildrew AG, Flowers EJ, Trimmer M (2007) Emission of methane from chalk streams has potential implications for agricultural practices. Freshw Biol 52:1176-1186

Schmid MC, Risgaard-Petersen N, van de Vossenberg J, Kuypers MMM and others (2007) Anaerobic ammonium oxidizing bacteria in marine environments: widespread occurrence but low diversity. Environ Microbiol 9: $1476-1484$

- Thamdrup B, Dalsgaard T (2002) Production of $\mathrm{N}_{2}$ through anaerobic ammonium oxidation coupled to nitrate reduction in marine sediments. Appl Environ Microbiol 68: 1312-1318

Trimmer M, Nicholls JC, Deflandre B (2003) Anaerobic ammonium oxidation measured in sediments along the Thames Estuary, United Kingdom. Appl Environ Microbiol 69:6447-6454

> Trimmer M, Nicholls JC, Morley N, Davies CA, Aldridge J (2005) Biphasic behavior of anammox regulated by nitrate and nitrite in an estuarine sediment. Appl Environ Microbiol 71:1923-1930

Trimmer M, Risgaard-Petersen N, Nicholls JC, Engström P (2006) Direct measurement of anaerobic ammonium oxidation (anammox) and denitrification in intact sediment cores. Mar Ecol Prog Ser 326:37-47

Weiss RF (1974) carbon dioxide in water and seawater: the solubility of a non-ideal gas. Mar Chem 2:203-215

Submitted: July 4, 2008; Accepted: January 26, 2009

Proofs received from author(s): March 24, 2009 